\title{
Political and Economic Analysis of Southeast Asian Regional Economic Integration Under China’s Rise-From Taiwan’s Perspective View
}

\author{
Rachel Sun, Shang-Yung Yen \\ Feng Chia University, Taiwan, R.O.C.
}

\begin{abstract}
This article seeks to answer why Taiwan has targeted Southeast Asia in its external economic strategy, and how the China factor has influenced the development of Taiwan-ASEAN economic relations. Worried about the political and economic risks inherent in Taiwan's growing economic dependence on China, as well as Taiwan's marginalization in regional economic integration, Taiwanese presidents since Lee have all emphasized the need to enhance trade and investment ties with Association of Southeast Asian Nations (ASEAN) countries. While the complementary natures of Taiwan's and Southeast Asia's economies place Taiwan in a favorable position to "Go South”, sovereign disputes in cross-Strait relations prevent the island from negotiating bilateral or multilateral trade agreements with ASEAN countries. The article argues that hedging is the most rational and viable option for Taiwan to manage political and economic analysis of Southeast Asian regional economic integration and under China's rise. The article examines the four major components of this strategy, namely, economic pragmatism, direct engagement, hard balancing, and soft balancing. The article goes on to assess the significance of each component and details how Taiwan has pursued its hedging strategy towards Southeast Asian regional economic integration.
\end{abstract}

Keywords: New Southbound, ASEAN, hedging, FTA

\section{Introduction}

Despite having official ties with just 18 mainly developing countries in the Pacific, West Africa, and Central America, Taiwan signed free-trade agreements with New Zealand and Singapore in 2013. All other investor-protection agreements it has with other countries were signed decades ago. Due to the diplomatic dilemma of Taiwan, which leads to decrease in exporting, in addition, China's economy has impact on Taiwan's economy and industry in the emerging of global economy integration era.

Taiwan has been waging heavy proportion of investment on China for many years. Therefore, the government raised the Go-South Policy in 1993 and tried to decrease economic dependence on China by strengthening economic cooperation with Southeast Asian countries, improving Asia Pacific regional economic development, and setting down its own industrial advantages.

Since 1997, China has been developing close cooperative ties with the Association of Southeast Asian Nations (ASEAN) countries and participating actively in regional affairs and conferences in Southeast Asia.

Rachel Sun, Ph.D. Program in Business, Feng Chia University, Taiwan, R.O.C.

Shang-Yung Yen, Ph.D. Program in Business, Feng Chia University, Taiwan, R.O.C. 
Since the Opening and Reform, China's economic power and comprehensive power have increased dramatically. However, the increasingly tightened interdependence also worries ASEAN states. In order to counterbalance this asymmetric relationship, the ASEAN states manipulate power leverage to balance external influences. The U.S. continues to increase emphasis on Asia Pacific and conduct strategic shift from the rebalancing strategy to Indo-Pacific strategy, hence making Southeast Asia the platform for active great power competition.

This article argues that Taiwan's Southeast Asian regional economic integration policy has been shaped by a delicate combination of various approaches best described as a multi-tiered, omni-directional hedging strategy. The strategy is composed of four major components: economic pragmatism; direct engagement; hard balancing; and soft balancing. Accordingly, Taiwan has made efforts to promote economic cooperation with Southeast Asian and directly engage it in various bilateral arrangements to boost mutual trust and cooperation. At the same time, it has also pursued a balancing strategy against China, which is composed of a "hard" component, providing major stakeholder powers of Indo-Pacific, with whom these interests converge, and a "soft" one aimed at promoting the New Southbound Policy to reinvigorate and diversify Taiwan's economy. The soft balancing component also involves Taiwan's efforts to deepen its ties with foreign powers to counter undue pressure from China.

The article is divided into three main sections. The first section provides an overview of ASEAN economic tie with Taiwan, China, and U.S. respectively. The second analyses Taiwan's hedging strategy, the rationale and foundations of the strategy in the Taiwan context. The third investigates how the strategy has been developed and operationalized by Taiwan.

\section{Theory of Hedging}

Even among the few who have attempted to develop the hedging concept and give it greater definitional rigor, the notion of hedging in IR remains "problematic" (Goh, 2006). Richard Weitz (2001) employed scenario planning to argue for a set of "shaping and hedging" strategies to address the issue of the U.S. response to China's rise. Weitz's other important contribution was his application of the idea of hedging to great power relations which was followed by similar approaches from other scholars.

Deficiencies in existing definitions, Goh (2006) defined hedging as a set of strategies aimed at avoiding (or planning for contingencies in) a situation in which states cannot decide upon more straightforward alternatives such as balancing, bandwagoning, or neutrality. When hedging, states seek to "cultivate a middle position that forestalls or avoids having to choose one side at the obvious expense of another". However, when pursuing hedging, a state oftentimes does not choose a middle position. Rather, it takes opposite positions.

Tessman and Wolfe (2011) defined strategic hedging as an insurance policy that helps states guard against two possibilities: That relations between the hedging state and the system leader will deteriorate to the point of a militarized crisis, and/or that the system leader will cease the provision of public goods that the hedging state currently enjoys.

Many China's neighbors have in recent years adopted a strategy of "looking to China for profit, the U.S. for security”. It is essentially establishing negative correlation through reverse operation: On the one hand, they intend to engage China and strengthen economic ties so as to share the dividends brought by the rise of China; on the other hand, they would like to hedge against the uncertainties and risks brought by the rise of China by strengthening military alliances or partnerships with the U.S. bolstering or establishing military alliances or 
partnerships with the U.S.

In essence, hedging is a strategy to enable states to deal with uncertainties in their partners' future behaviour by relying on a basket of policy tools that, while helping to promote bilateral cooperation, also entails competitive elements aimed at preparing themselves against potential security threats posed by their partners (Kuik, 2008). The policy tools available in this basket are virtually the same for every state and situated anywhere along a continuum extending from pure bandwagoning to pure balancing. According to Kuik Cheng-Chwee (2008), for example, these tools include limited bandwagoning, binding engagement, economic pragmatism, dominance denial, and indirect balancing.

However, each country's position on the bandwagoning-balancing continuum, as well as the significance of specific tools used in the strategy, varies from country to country, mainly depending on their security concerns vis-à-vis China (Goh, 2005). The diversity and convertibility of the tools enable states to easily move back and forth along the bandwagoning-balancing continuum, depending on developments in bilateral relations and changes in the international environment. The following two sections examine ASEAN's economic tie with Taiwan, China, and U.S. respectively and the foundations of Taiwan's hedging strategy and its operationalization.

\section{ASEAN-Taiwan Economic Tie}

The likely potential conflict that will erupt, in the region that involves China, is the Taiwan issue. China will not sit by and watch Taiwan become independent as it always persists on the "one-China Policy". While political elites on both sides of the Taiwan Strait have a great interest in avoiding military conflict, hostility is still a probability. A military conflict in the Taiwan Strait poses a direct threat to the stability of the entire region. The stability of the region is in U.S., China, and ASEAN members' vital national interest.

\section{Taiwan's Economic and Trade Development in ASEAN}

ASEAN and South Asian nations encompass 32\% of the world's population and have a combined GDP of \$5.1 trillion. Global Insight estimates that the annual economic growth rate for ASEAN and South Asian countries will be between 4.9 and 7.4\% from 2017 and 2021. The developed economies of Australia and New Zealand offer safe, highly regulated investment environments.

Since 2008, ASEAN has become Taiwan's second largest export market, second only to China, with 18\% of Taiwanese exports going to ASEAN. ASEAN has been the third largest source of imports to Taiwan since the year 2000, second only to China and Japan, with 12\% of Taiwanese imports originating from ASEAN countries in 2016. Taiwan is also one of the largest investors in ASEAN countries, with cumulative investment of US\$87 billion in the 30 years up to 2016, making it second only to China. From 2011-2016, 51\% of Taiwanese investment in the ASEAN 6 countries (Thailand, Indonesia, Malaysia, the Philippines, Singapore, and Vietnam) was in the manufacturing sector, while $49 \%$ was in the service sector, according to Chung-hua Institute of Economic Research (CIER) researcher Yang Shu-fei.

\section{Taiwan's Participation in the Trade Arrangements}

Taiwan is a party to only five FTAs that have been signed and ratified. These are agreements with Panama (2004), Guatemala (2005), Nicaragua (2008), El Salvador (2008), and Honduras (2008). As noted, on July 10, 2013, Taiwan signed its latest agreement with New Zealand and with Singapore.

Taiwan has been absent from the proliferation of Asian FTAs. The growth in Asian FTAs has underpinned 
increased Asian economic regionalism. ASEAN countries have made important progress in liberalizing trade under an ASEAN FTA. ASEAN has also negotiated a number of FTAs, who have commenced negotiations towards a Regional Comprehensive Economic Partnership (RCEP) and also part of the Trans-Pacific Partnership (TPP) negotiations, will give these countries preferential market access to the developed markets of the United States, Canada, Japan, Australia, and New Zealand. Additionally, successful completion of a Korea-China FTA will strengthen Korea as a gateway for other countries to trade and invest with China, competing with Taiwan's ability to use Economic Cooperation Framework Agreement (EFCA) to play a similar gateway role.

For Taiwan to reap the full benefit from its growing services sectors requires reform. Liberalizing its services market under an FTA would open the services sector to competition and lead to improved productivity. Moreover, as services are often important inputs into the manufacturing and industrial sectors, increased productivity in the services sector will flow through to the overall economy.

\section{How Integrated Are China and Taiwan}

Under President Ma Ying-jeou, Taiwan has pursued ever closer economic integration with China. The most significant vehicle for this is the Economic Cooperation and Framework Agreement (ECFA) which entered into force on 12 September 2010. The ECFA, as its name suggests, provided a framework for further negotiations aimed at liberalizing trade in goods, services, and investment.

For Taiwan, ECFA serves a range of goals. These include: economic growth; becoming a gateway for foreign investment into China; stimulating increased purchases by Chinese companies of inputs from Taiwan, thereby strengthening Taiwan's position in the Asian supply chain; and helping transform Taiwan into a regional industrial center.

According to some estimates, ECFA will increase Taiwan's GDP by $1.7 \%$ and create 260,000 jobs. As China is Taiwan's number one trading partner and investment destination, ECFA should lead to further strengthening of the bilateral trade and economic relationship and underpin the existing supply chain relations outlined above.

ECFA has not been without domestic political challenges for President Ma and the Kuomintang. Concerns remain that the closer economic integration that ECFA will usher in will make Taiwan increasingly dependent on China and thereby give China greater leverage that could be used to achieve its goal of political unification. Chinese Foreign Minister Wang Yi (former director of the mainland's Taiwan Affairs Office) claimed in a speech at Brookings on September 20, "Gradual integration of the two sides [of the Taiwan Strait] through two-way interactions and cooperation will lead to ultimate reunification”.

\section{ASEAN-China Economic Tie}

Economic policy is obviously an important part of overall political calculus, and this piece argues that $\mathrm{Xi}$ has three fundamental, short-term objectives for economic policy, each of which reflects the need to sustain a positive domestic narrative about his leadership. The three narratives are: (1) The economy is growing stably (at least up through the Party Congress); (2) Economic reforms are moving ahead; and (3) A revitalized China is playing an increasingly important leadership role in global economic policy. Xi looks set to be able to maintain the plausibility of all three of these narratives through 2017, greatly strengthening his political position. 


\section{ASEAN-China Free Trade Area}

The ASEAN-China Free Trade Area (ACFTA), also known as China-ASEAN Free Trade Area, is a free trade area among the ten member states of the ASEAN and the People's Republic of China. The initial framework agreement was signed on 4 November 2002 in Phnom Penh, Cambodia, with the intention to establish a free trade area among the 11 nations by 2010. The free trade area came into effect on 1 January 2010. The ASEAN-China Free Trade Area is the largest free trade area in terms of population and third largest in terms of nominal.

Economically, the ASEAN-China FTA has effectively linked China closer to ASEAN. The FTA will enhance a sense of community within East Asia and lay the foundation for broad regional economic cooperation ensuring peace and stability. This will result in the world's biggest free trade zone. For both sides, there should be net trade gains: Trade creation would offset trade diversion with ASEAN getting a slight trade diversion while the same trade diversion would not be obvious for China. With China's strong growth, it seems that China would require more input imports and ASEAN could provide as an alternative source of inputs for natural-resource based and intermediate inputs in an FTA.

\section{Changes After 19th National Congress}

The Chinese Communist Party (CCP) embarked on its own "Game of Thrones" as delegates gather for its 19th National Congress in Beijing. A variety of posts will be filled for the next five years-including the vitally important General Secretary of the CCP (President of the People's Republic of China or PRC), as well as members of the Standing Committee. These individuals will find themselves leading a massive organization, which has more than 80 members, and running what is arguably the world's largest economy. They will wield considerable powers but the incumbent leader is unlikely to relinquish his grip on power.

Yet for all these technological developments, there are still significant challenges for China: rural poverty, environmental degradation, and the economic turbulence generated by the "new normal"-China is now transitioning from export-led economic growth to consumer-driven growth. The Xi-Li administration has sought to tackle these problems as part of the "Chinese Dream"—or national "rejuvenation"—which aspires to attain a "moderately prosperous society”. Recently, China’s neighbors have been unnerved by territorial disputes in the South China Sea and by the steady advance of the PRC's military.

\section{Balance of Power in the Southeast Asia Region}

China's huge size and its rapid growth are enough to disrupt the balance of power in the Southeast Asia region. It is natural to cast China as the regional hegemony. The international community welcomes a strong China because a weak and insecure China would bring nothing but trouble to the region. Largely, China's relation with ASEAN clearly reflects realist bias where national interests and security are the main agenda.

As mentioned, China's strategic culture is anti-hegemonic, and China will use force quite readily; China persists, repetitiously, that defense is its policy. Thus, ASEAN members inevitably will maximize their diplomatic and political instruments of national power into play. ASEAN countries recognized this; therefore, it is not surprising that cooperation between ASEAN and China has grown tremendously in various areas after the establishment of ASEAN-China Consultative Dialogue in 1994. The current economic performance of China and ASEAN, and greater political stability, peace, and security as a whole in the region, is a reflection of the current cooperation. 


\section{ASEAN-U.S. Economic Tie}

The U.S. will continue to safeguard the regional balance of power and ensure open trade. Due to China's growing military and economic power, ASEAN prefers that the U.S. remains engaged in the region and act as a counterbalance to China's influence.

\section{U.S. as a Balance of Power}

The U.S. security concern in this region is to prevent the domination of an unfriendly power and assure U.S. political access and influence. In addition to terrorism, the stability of this region is likely to be challenged by several issues, such as those on the Korean Peninsula, the rising tension between China-Taiwan, India-Pakistan, and at the South China Sea. Since ASEAN countries are no match for China's superiority, the role of the U.S. as an "honest broker" or balancer of security interests in the region is still relevant. ASEAN realized that an effective antidote to a power is another power. The Philippines, Singapore, Thailand, and Indonesia, have traditionally looked to the U.S. to keep a balance with China. For the nations in East Asia, the U.S. remains the only power capable of influencing China's behavior.

Over the past years, the U.S. has significantly increased its engagement of ASEAN and its member nations. The region, which includes leading moderate Islamic countries, was quick to join the world in the war against terrorism. U.S. exports to ASEAN are more than twice as large as its exports to China. Therefore, access and participation in ASEAN markets is important to the economic futures of both the U.S. and ASEAN countries.

\section{TPP Have Three Positive Impacts on China}

The idea that TPP was "excluding China" has always been an exaggeration, and there was always the long-run possibility that TPP would benefit China by encouraging a broader (competitive) opening of the Chinese economy. In the short run, however, Trump's withdrawal from the TPP, dissolved an economic agreement primarily among like-minded allies, and inevitably benefitted China in its role as economic and geopolitical rival of the U.S. While TPP was not directed against China, the end of TPP will have three positive impacts on China and especially on Xi Jinping.

First, TPP would have improved the competitive position of some of China's economic competitors, especially Vietnam. Second, TPP would have oriented the economies of member countries more toward the U.S. market. Third, TPP would have created a new template of international economic regulation. However, even more important were provisions opening service sectors in which the U.S. has competitive advantage. These rules naturally reflect American interests, and would have paved the way for broader multinational agreements that incorporate the same rules. Trump’s cancelling of TPP was a gift to China.

\section{From Globalization to Regionalization}

After the worldwide crisis of 2008/9, global economic integration has slowed, but regional economic integration has intensified, especially efforts toward free trade agreements in Asia. In the past, Taiwan's rapid growth relied on globalization. Today, it must thrive with regionalization. After all, in 2012, the mainland and Hong Kong SAR accounted for more than $40 \%$ of all Taiwan's exports. Without these export destinations, Taiwan's export-led growth would collapse.

In the future, much of global growth will be driven by the mainland and emerging Asia. The intensified regional integration is reflected by the ongoing talks over the U.S.-led TPP and the RCEP which includes the mainland. Meanwhile, ASEAN integration is accelerating. In addition to these regional trade blocs, talks 
continue over bilateral free trade and investment agreements between different economies in Asia and the U.S. or European Union.

\section{Taiwan's Hedging Strategy}

Taiwan seeks to exploit conditions conducive to bilateral cooperation, especially in the economic sphere, to promote its domestic development. On the other hand, competing claims in the South China Sea and China's increasingly threatening posture dictate that Taiwan must "struggle" with China in this aspect to best protect its national interests. In effect, Taiwan has been developing the strategy with four major components in mind as Figure 1:

1. Economic pragmatism, i.e., deepening bilateral economic cooperation to facilitate domestic development.

2. Direct engagement, i.e., expanding and deepening various bilateral mechanisms to build mutual trust and nurture cooperation, thereby shaping China's behavior.

3. Hard balancing, i.e., providing major stakeholder powers of Indo-Pacific, with whom these interests converge to deter China from aggressive actions.

4. Soft balancing, i.e., promoting the New Southbound Policy to reinvigorate and diversify Taiwan's economy, also deepening relations with major partners to counter against undue pressure from China.

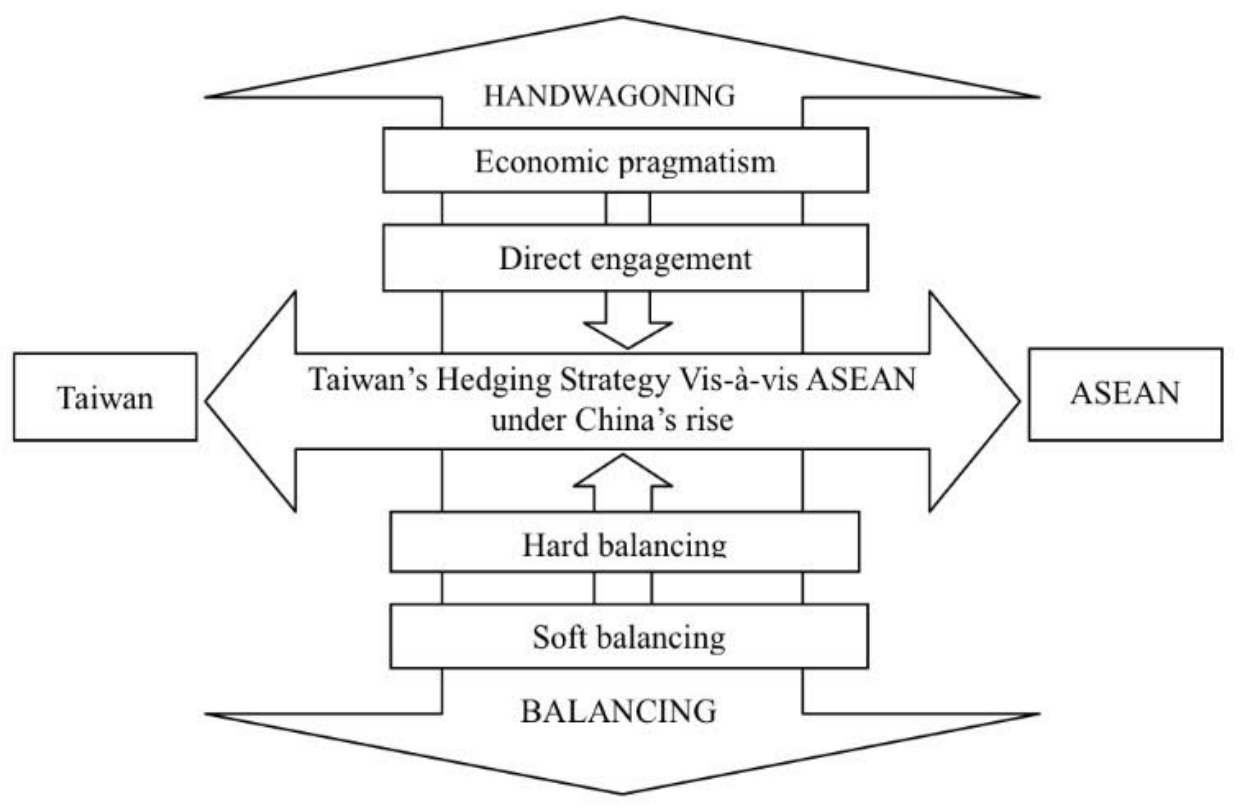

Figure 1. Taiwan’s hedging strategy vis-à-vis ASEAN under China’s rise.

Figure 1 illustrates the components and the operational mechanisms of Taiwan's hedging strategy vis-à-vis ASEAN under China's rise. It is obvious that the first two components-namely economic pragmatism and direct engagement - tend to slide towards the bandwagoning end of the balancing-bandwagoning continuum, while the remaining two components are situated towards the opposite end. The individual components of the strategy will now be analyzed to highlight how Taiwan has operationalized this strategy. 


\section{Economic Pragmatism}

Trade and investment ties with Taiwan have undeniably contributed to the economic growth of ASEAN over the last decades. Despite its asymmetric nature, economic ties obviously thicken the network of bilateral interactions, which serve as a cushion to absorb tensions arising from other domains of the bilateral relationship, including those related to the South China Sea dispute.

In the process of Asia's economic development, Taiwan has played a very important role by acting as a resource consolidator and a provider of capital and technology over the past several decades. For example, Taiwan is the third-largest investor in Thailand, with accumulated investment amounting to US $\$ 14.1$ billion by the end of 2016, and fourth in Vietnam (US\$31.2 billion) and Malaysia (US\$12.2 billion). Apart from the suitable investment environment, there are many other reasons why Taiwanese companies perform very well in the region, including Taiwan's workforce talent, its good reputation, and its ability to provide a match for the business demands of the New Southbound countries.

Taiwanese businesses have not only been doing very well, but are also striving to cultivate business roots and engage local communities, in the process contributing to the economic and social development of many New Southbound countries. Taiwan's greatest advantage in heading south lies in its experience with small-scale enterprises.

Taiwan's distinct economic structure-mostly smaller business entities such as farmers, fishermen, and small-scale enterprises - matches the economic structure of Southeast and South Asian countries. Taiwan's experience in successfully developing small-scale business structure is of great value to the countries in that region.

Deepened bilateral economic ties tend to raise the stakes for all parties to the point that they may ultimately favour a cooperative and stable bilateral relationship rather than an antagonistic one. Therefore, such logic obviously still makes Taiwanese strategists consider economic pragmatism as an important component of the country's hedging strategy against ASEAN under China's rise.

\section{Direct Engagement}

Engagement is the promotion of bilateral communication and mutual trust, thereby facilitating cooperation and providing effective avenues to address conflicts of interests that may otherwise do serious harm to the overall relationship. In effect, Taiwan has paid serious attention to building a network of engagement with ASEAN through three major channels: government-to-government, party-to-party, and people-to-people interactions. As explained below, these efforts have led to positive results.

The exchange of visits between high-ranking leaders as summarized in Table 1 to Table 3, between 2014 and 2016, Taiwan and Asia-pacific exchanged visits by top party and state leaders. These visits normally witnessed the signing of agreements to promote bilateral cooperation in various fields. More importantly, they helped set the larger political framework for bilateral relations. Apart from high-ranking visits, other important cooperative mechanisms between the two governments have also been established. As shown in Table 4, in addition to the key mechanisms mentioned above, there are also other arrangements through which Taiwan and Asia-pacific engage each other in different aspects of their bilateral relationship. These engagements generate a network of frequent interactions, thereby improving bilateral communication and minimizing the risk of misunderstandings or misperceptions. 
Table 1

Numbers of Taiwan Visits to Foreign Countries by Category in Asia-Pacific

\begin{tabular}{llllll}
\hline Year & Total & Governmental officials & Elected representatives & Scholars & Others \\
\hline 2016 & 755 & 435 & 96 & 36 & 188 \\
2015 & 3,033 & 1,027 & 177 & 109 & 1,720 \\
2014 & 1,804 & 921 & 140 & 127 & 616 \\
\hline
\end{tabular}

Source: Ministry of Foreign Affairs.

Table 2

Number of Foreign Visitors to Taiwan by Category in Asia-Pacific

\begin{tabular}{|c|c|c|c|c|c|c|c|c|c|c|c|c|c|c|}
\hline \multirow[b]{2}{*}{ Year } & \multirow[b]{2}{*}{ Total } & \multicolumn{9}{|c|}{ Government officials } & \multicolumn{3}{|c|}{ Legislators } & \multirow[b]{2}{*}{$\begin{array}{l}\text { Others (from } \\
\text { other sectors) }\end{array}$} \\
\hline & & 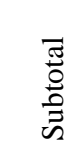 & 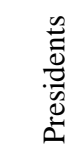 & 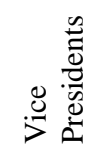 & 童泀 & 尝离离 & 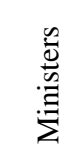 & 可 & 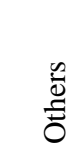 & 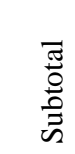 & 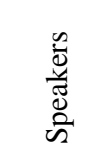 & 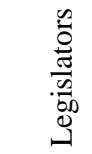 & 总 & \\
\hline 2016 & 3,860 & 776 & 5 & 2 & 2 & - & 25 & 46 & 696 & 345 & 4 & 134 & 207 & 2,739 \\
\hline 2015 & 3,371 & 941 & 5 & - & 1 & - & 18 & 76 & 841 & 313 & 7 & 134 & 172 & 2,117 \\
\hline 2014 & 3,888 & 979 & 4 & 2 & 1 & - & 23 & 175 & 774 & 460 & 7 & 223 & 230 & 2,449 \\
\hline
\end{tabular}

Source: Ministry of Foreign Affairs.

Table 3

Taiwan Participation in International Conferences and Events in Asia-Pacific

\begin{tabular}{llllll}
\hline \multirow{2}{*}{ Year } & \multirow{2}{*}{ Total } & \multicolumn{4}{c}{ International conference } \\
\cline { 3 - 6 } & & Subtotal & Governmental & Private sector & 238 \\
\hline 2016 & 470 & 232 & 69 & 163 & 262 \\
2015 & 1,385 & 1,123 & 103 & 1,020 & 271 \\
2014 & 1,631 & 1,360 & 166 & 1,194 & 2 \\
\hline
\end{tabular}

Source: Ministry of Foreign Affairs.

Table 4

Number of Bilateral Agreements and Treaties Signed

\begin{tabular}{|c|c|c|c|c|c|c|c|c|c|}
\hline Year & Total & $\begin{array}{l}\text { Navigation } \\
\text { rights }\end{array}$ & Taxation & $\begin{array}{l}\text { Investment } \\
\text { guarantees }\end{array}$ & $\begin{array}{l}\text { Protection } \\
\text { of IPR }\end{array}$ & $\begin{array}{l}\text { Technology/ } \\
\text { Culture }\end{array}$ & $\begin{array}{l}\text { Agriculture, fisheries, } \\
\text { husbandry, mining and } \\
\text { handicrafts }\end{array}$ & Medical care & Others \\
\hline 2016 & 36 & 2 & 2 & - & 1 & 3 & 4 & 2 & 22 \\
\hline 2015 & 40 & - & 1 & 1 & 3 & 5 & 6 & - & 24 \\
\hline 2014 & 43 & - & 2 & 1 & - & 7 & 4 & 3 & 26 \\
\hline
\end{tabular}

Source: Ministry of Foreign Affairs.

\section{Hard Balancing}

The Indo-Pacific strategy is a preliminary idea for the U.S. to connect the Indian Ocean and the Pacific region, constrain China's rise from a geopolitical perspective, and safeguard its own leadership and interests in the region.

The Indo-Pacific strategy is still a concept that needs to be constructed and the quadrilateral security dialogue — the Quad formed of the United States, Japan, India, and Australia—is only the beginning of the construction of the Indo-Pacific security region. Moreover, many scholars believe that the Indo-Pacific strategy 
is simply the descendant of and an expansion on the Obama administration's "rebalance" strategy. The Indo-Pacific strategy is essentially an extension and deepening of the "rebalance” with the aim of strategically linking the Indian and Pacific Oceans.

Since the beginning of the current decade, the U.S. administration realized the inadequacy of the "Asia-Pacific" to meet its geopolitical and attendant foreign policy objectives in Asia, for two key reasons. The first was China's expanding politico-military activities from the western Pacific to the Indian Ocean. The second was the imperative to incorporate New Delhi into the region-wide security architecture. "Indo-Pacific" focuses on the security dimension of America's geopolitical ends-primarily relating to China-that necessitated a more robust collaboration with U.S. allies and partners. The "Indo-Pacific" construct provides Taiwan a valuable opportunity to partner with the resident countries and major stakeholder powers of Indo-Pacific, with whom these interests converge.

\section{Soft Balancing}

Taiwan's attempt is to avoid economic dependence on China. President Tsai Ing-wen is attempting to reinvigorate and diversify Taiwan's economy. Currently, trade with China constitutes over 20\% of Taiwan's total trade. The over $\$ 100$ billion in cross-Strait trade is nearly double that of Taiwan's second largest trading partner, the United States, leaving the island nation heavily reliant on the Chinese economy. Tsai's push for new regional partners, called the "New Southbound Policy", is similar but more strategic than the policies of former President Lee and Chen. Like its forerunners, Tsai's policy seeks to lessen the mainland's dominance of Taiwan's trade, but it is more comprehensive and emphasizes building an extensive network of cultural and interpersonal relationships throughout the region.

Furthermore, Taiwan's trade with China is compounded by a contentious political environment. Unlike other small nations that are dependent on large trade partners, Taiwan must also contend with its disputed sovereignty, leaving it uniquely vulnerable to coercion from China.

Essence of the New Southbound Policy is to forge a new and mutually beneficial model of cooperation, and create a sense of economic community. Rather than unilaterally setting up contract manufacturing bases in ASEAN and South Asia as in the past, Taiwan will pursue bilateral partnerships and expand exchanges of personnel, capital, technology, culture, and education with ASEAN, South Asian states, Australia, and New Zealand. These efforts will forge a new and mutually beneficial model of cooperation and ultimately create a sense of economic community. To build strategic partnerships that will create regional prosperity, the plan outlines four tasks:

(1) Promote economic collaboration. Forge new partnerships by integrating with those countries' supply chains, connecting with their domestic demand markets. Taiwan will support the industrial capacities and demands of partner countries through the five major innovative industries it is currently developing. And create a collaborative platform for exporting infrastructure construction services and turnkey projects.

(2) Conduct talent exchange. With a focus on people, deepen bilateral exchange and cultivation of young scholars, students, and industry professionals. Expand scholarships to draw more students from ASEAN and South Asia. Establish a points-based system allowing residency extensions for eligible foreign professional or technical workers in Taiwan. Help generation immigrants use their linguistic and cultural advantages to obtain work certification and job opportunities.

(3) Share resources. Capitalize on Taiwan's soft powers to promote bilateral and multilateral cooperation 
in culture, tourism, medical care, technology, agriculture, and small and medium-sized enterprises. Cooperate on bilateral pharmaceutical certifications. Use film, broadcasting, and online games to market Taiwan's cultural brand. Ease visa requirements for tourists.

(4) Forge regional links. Systematize bilateral and multilateral cooperation with partner countries while strengthening negotiations and dialogue. Promote multilevel and all-encompassing negotiations and dialogue. Open dialogue and negotiations with China at a suitable time on relevant topics and cooperation matters. Reallocate foreign aid resources. Build a comprehensive foreign aid mechanism.

\section{Taiwan Operationalizing the Hedging Strategy}

Further we investigate Taiwan's tactics and means regarding the regional integration of ASEAN under the rapidly changing international context: a global economy in disarray, highly uncertain and confrontational regional politics, falling levels of domestic investment, a bottleneck in the transformation of the manufacturing industry, difficulty expanding into international markets, and a continued overreliance on China as an export market.

\section{Two-Pronged "Southbound" Strategy}

The "New Southbound Policy" and its "five innovative industries policy" to promote creative industries have both been keenly anticipated. Taiwan government would open a series of service centers; one for each of the 18 countries covered by the "New Southbound Policy", and instructed the Financial Supervisory Commission to set up a "southbound center" financing platform for Taiwanese businesses in need of capital injections. Governments at all levels would have to divide responsibilities in a specialized manner as the Cabinet sets out a plan for how state machinery would be used to implement the policies, establish key performance indicators, and do promotional work.

When mulling the "New Southbound Policy" and the "five innovative industries policy", perhaps thoughts should be focused on how to best furnish Taiwanese businesses with a competitive advantage, based on the principle of incremental innovation and complemented by disruptive innovation and the integration of new and old industries. Exports to the 18 countries covered by the government's New Southbound Policy increased by 14\% in 2017 as Table 5. Taiwan's exports to the 18 countries covered by the government's New Southbound Policy picked up more steam during the first year, reflecting the effectiveness of the initiative in driving the local economy.

Table 5

Import and Export Trade Value Table Amount: Million U.S. Dollars

\begin{tabular}{lllllllll}
\hline \multirow{2}{*}{ Year } & \multicolumn{3}{c}{ China } & \multicolumn{3}{c}{ New South (18) } \\
\cline { 2 - 9 } & Trade & Export & Import & Balance & Trade & Export & Import & Balance \\
\hline 2015 & 115,392 & 71,209 & 44,183 & 27,026 & 96,357 & 59,236 & 37,121 & 22,116 \\
2016 & 117,868 & 73,878 & 43,990 & 29,889 & 95,954 & 59,415 & 36,539 & 22,876 \\
2017 & 139,022 & 88,980 & 50,041 & 38,939 & 110,801 & 67,375 & 43,426 & 23,948 \\
$2018(01 \sim 02)$ & 21,852 & 13,454 & 8,398 & 5,056 & 17,769 & 10,650 & 7,119 & 3,530 \\
\hline
\end{tabular}

Source: Ministry of Economic Affairs.

\section{Not Intended to Compete or Replace the One Belt, One Road}

It is not a point-to-point or direct response. Taiwan had the (old) Southbound Policy in the 1990s under (then) president Lee Teng-hui. At that time, there was no such initiative as One Belt One Road. Taiwan's 
direction (forward) is to have market diversification; Mainland China is only one of Taiwan's most important markets and investment opportunities. The New Southbound Policy is not a competition with the One Belt one Road initiative.

The New Southbound Policy is not intended to compete or replace the One Belt, One Road. Taiwan has transformed over years and accumulated knowledge, experience, willing to share hard-earned knowledge with neighbors. In 2016, Taiwan-made products were ranked No. 1 in the world market; 23 were ranked among the top three. These products were in the semiconductor foundry market, IC packaging and testing, high-end bicycles, glass fiber cloth, green algae, functional textiles, and portable navigation device. Taiwan has lots of natural disasters and lack of natural resources, but the government is investing heavily in human resource. That is why Taiwan is called the economic miracle of Asia.

\section{An Integrated ASEAN Would Attract More Foreign Investments}

The New Southbound Policy is aimed at reducing Taiwan's economic dependence on China. The number of tourists visiting Taiwan from the 18 designated countries totaled 513,457 in the first quarter of 2017, up $33.26 \%$ from the same period in 2016. Taiwan's trade with these countries 10\% increases year-on-year. In terms of educational exchanges, Taiwan welcomed 31,531 students from the target countries for the current school year, up 9.7\% from the previous school year.

An integrated ASEAN would attract more foreign investments and improve their economic competitiveness through economies of scale and specialization according to comparative advantages of each member states. China today has become an economic opportunity for ASEAN since Beijing has deliberately changed its strategic engagement with ASEAN as China seeks stability and equilibrium for its own economic development. In terms of the U.S.-ASEAN relations, the U.S.-ASEAN two-way trades totaled $\$ 120$ billion last year. With the growing importance of the ASEAN region, the U.S. role in this region is poised to increase in the future.

\section{Building Integration With China, From Goods to Services}

In the summer of 2010, Taiwan and the mainland agreed on the EFCA. The preferential trade agreement reduced tariffs and commercial barriers between the two sides and boosted bilateral trade to $\$ 197$ billion last year. From the standpoint of bilateral trade, the Cross-Strait Service Trade Agreement (CSSTA) is a vital follow-up to the ECFA. It would open Taiwan's industries to mainland investment, while the mainland would open industries to Taiwan's investment.

While the CSSTA is just one of many proposed trade agreements to the mainland, it is a critical lifeline to Taiwan. First of all, the CSSTA would allow Taiwanese businesses to broaden and deepen their economic expansion in the mainland. Also, the ECFA focuses on goods, while the CSSTA stresses services. Goods are important in the early stages of economic development, whereas services are vital in the more advanced stages of development. The CSSTA supports Taiwan's efforts to move higher in the value-added chain, while boosting reforms that support the transition of the mainland economy from cost-efficiencies toward innovation-driven competitiveness. Third, the CSSTA is vital to protect Taiwan's current sources of competitive advantage and build new sources of advantage. Finally, it also paves way for further economic integration with other nations in Asia, which is critical to Taiwan's future. 


\section{Conclusion}

ASEAN has earned a growing recognition in international community, and has clearly demonstrated the gains of political cooperation. The territorial disputes in the South China Sea are a major security concern not only to the claimants but also to the international community. Above all conclusion is as below as follow.

\section{Stabilized ASEAN-China Relation Should Help Stabilize the Asia-Pacific Region}

ASEAN hopes to benefit from China's modernization program by taking advantage of economic opportunities. ASEAN states worry about whether it will use its newfound power to seek regional hegemony, resolving territorial disputes by force and interfering in the internal affairs of its neighbors. Nevertheless, lately, China appears to have adopted a more accommodating attitude towards these disputes. China has demonstrated the willingness for dialogue.

China and ASEAN future relations will be a mixture of cooperation on some front sand unresolved issues conducive to tension on the other fronts. A stabilized ASEAN-China relation should help stabilize the Asia-Pacific region, which is what both ASEAN and China seek to develop and prosper together. In summary, the relations between China and ASEAN clearly reflect the dictum "there is no permanent enemies or friends only permanent interest”. Hence, the U.S. is always welcomed as a counterbalance in the region.

\section{Political Consensus to Support Economic Growth}

There is no doubt that the relation between China (PRC) — the largest developing country and the United States - the largest developed country is crucial to the world. In economic aspect, China and America are so intertwined that their symbiotic relationship is described as "Chimerica"; however, divergence always emerges between the two on political issues, in particular, the Taiwan issue. In a word, there is an increasing trend toward closer economic and trade relations among the three parties, and there are still a lot of common interests between the PRC and the U.S. as well as between Beijing and Taipei. A peaceful solution of the Taiwan problem is also possible in a foreseeable future.

Political consensus is to support economic growth. Nonetheless, in Taiwan and elsewhere, economic success is challenging without adequate political consensus. Conversely, political determination without sufficient economic growth will only result in stagnation. What Taipei needs is a political consensus that supports an economic pro-growth path; and that requires trade pacts with the mainland and the rest of the emerging Asia.

\section{Taiwan Economic Reform Including Liberalizing the Economy}

Taiwan is now facing a range of new challenges that will test anew the capacity of Taiwan's vibrant but still nascent democracy to pull together to address important issues. For one, its exclusion from trade agreements in the Asia Pacific region has undermined the competitiveness of its manufacturing sector and these impacts will grow as regional supply chains increasingly bypass Taiwan as businesses invest elsewhere to take advantage of these agreements' trade preferences. Taiwan's leaders must also overcome domestic challenges to introduce needed economic reform including liberalizing the economy to greater international competition and developing a competitive and innovative services sector-something increasingly important for an advanced economy.

\section{Participating in Trade Agreements and in Particular the TPP}

In this environment, participating in trade agreements—and in particular the TPP—is key, not only for the 
market access opportunities but as an impetus for the type of economic policies that Taiwan needs to adopt. But joining the TPP will present its own challenges, including U.S. wariness about Taiwan's capacity for the type of reforms that TPP membership will require, and likely opposition from China. However, the importance to Taiwan of participating in the growing sweep of trade liberalization in the Asia Pacific region is not a question for Taiwan of "if", but of "when". Navigating these domestic political restraints and implementing domestic economic reform while convincing China to support Taiwan’s participation in the TPP are the great challenges going forward.

\section{“New Southbound” Policy May Still Make Some Strides}

While the complementary natures of Taiwan's and Southeast Asia's economies place Taiwan in a favorable position to "Go South", sovereign disputes in cross-Strait relations prevent the island from negotiating bilateral or multilateral trade agreements with ASEAN countries. Given that President Tsai and President Xi Jinping have not found a basis for political cooperation, the prospects for Taiwan to reach more trade agreements with ASEAN countries remain dim. However, if the Tsai administration can mobilize resources in the financial and tourism sectors, the "New Southbound Policy" may still make some strides.

\section{References}

Brigadier General Ahmad Hasbullah Mohd Nawawi Malaysian Army, China-ASEAN future relations—an analysis. (2005). USAWC Strategy research project.

Goh, E. (2005). Meeting the China challenge: The US in Southeast Asian regional security strategies. Washington, D.C.: East-West Center.

Goh, E. (2006, August 31). Understanding “hedging” in Asia-Pacific security. In Pacific Forum CSIS PacNet (pp. 1-2).

Khurana, G. (2018). The origin of "Indo-Pacific" as geopolitical construct. Retrieved from https://thediplomat.com/2018/01/the-origin-of-indo-pacific-as-geopolitical-construct/

Kuik, C. C. (2008). The essence of hedging: Malaysia and Singapore's response to a rising China. Contemporary Southeast Asia, 30(2), 163, 166.

Ku, S. C. Y. (2005). The changing political economy of Taiwan's and China's relations with Southeast Asia: A comparative perspective. In China and Southeast Asia: Global changes and regional challenges (pp. 259-280).

President Tsai Ing-wen's Inaugural Address. (2016, May 20). Retrieved from http://english.president.gov.tw/Default.aspx?tabid=491\&itemid=37416\&rmid=2355\#

President Tsai's Remarks at Taiwan-ASEAN Dialogue. (2016, November 15). Retrieved from http://english.president.gov.tw/Default.aspx?tabid=491\&itemid=38323\&rmid=2355

Stuart, C. (2016). Opportunities and challenges: Taiwan's New Southbound Policy. Retrieved from http://en.naipo.com/Portals/0/web_en/Knowledge_Center/Feature/IPNE_161028_0703.htm

Steinbock, D. (2014). Why Taiwan needs regional integration. Economy Watch Follow the Money.

Tessman, B., \& Wolfe, W. (2011). Great powers and strategic hedging: The case of Chinese energy security strategy. International Studies Review, 13(2), 214-240.

Weitz, R. (2001). Meeting the China challenge: Some insights from scenario-based planning. The Journal of Strategic Studies, 24(3), 19-48. 